\title{
ITGAD Negative
}

National Cancer Institute

\section{Source}

National Cancer Institute. IT GAD Negative. NCI Thesaurus. Code C162061.

An indication that IT GAD expression has not been detected in a sample. 